
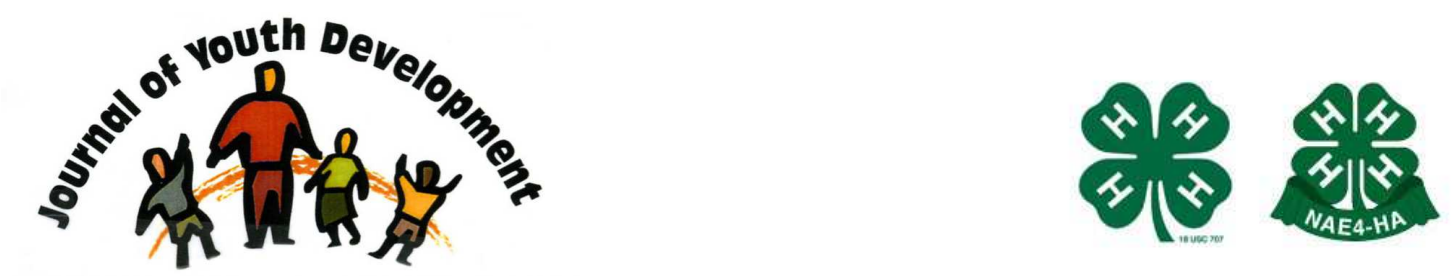

Bridging Research \& Practice

\title{
Employers Can Do Youth Development Too
}

\author{
Eric Vogel
}

University of Minnesota Extension Service

St. Cloud, MN

vogel007@umn.edu 


\title{
JOURNAL OF YOUTH DEVELOPMENT \\ bridging research and practice

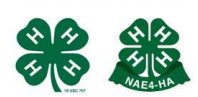

Volume 3, Number 2, Fall 2008

Article 080302FA004

\section{Employers Can Do Youth Development Too}

\author{
Eric Vogel \\ University of Minnesota Extension Service
}

\begin{abstract}
Professionals and volunteers who care about the welfare of young people know the importance of caring adults. The field has worked with all types of adults, including parents, teachers, and youth workers to enhance their understanding of youth development philosophy, approaches and practices. However, we've virtually ignored an entire sector of adults who play a major role in the lives of young people-employers. Given the large number of youth in the workforce, and understanding the critical role of caring adults, the question becomes, "how do we focus attention on preparing employers and other workplace adults to be more thoughtful and intentional about their interactions with young people?" The objective of this paper is to lay out the relevant issues and to begin the dialogue about building the capacity of employers to better support the development of our young people.
\end{abstract}

\section{Introduction}

Professionals who care about the welfare of young people know the importance of caring adults who support and nurture positive development of our youth. Armed with this understanding, the field has worked with all types of adults, including parents, teachers, and youth workers to enhance their understanding of youth development philosophy, approaches and practices. However, we've virtually ignored an entire sector of adults who play a major role in the lives of young people, mainly employers.

Unlike other developed countries where young people are expected to concentrate their energies on school, in the United States, it is almost an expectation that youth will both attend school and be employed (Greenberger \& Steinberg, 1986). While the number of young people working in paid jobs outside the home varies depending on how investigators collected the information, one study found that four out of five ninth graders had held a steady job at some point in their lives (Mortimer, 2003). The US Department of Labor (2000) reports that more 
than one in four sixteen year olds, and more than one in three seventeen year olds are in the labor force at any given time.

Given the large number of youth in the workforce, and understanding the critical role of caring adults, the question becomes, "how do we focus attention on preparing employers and other workplace adults to be more thoughtful and intentional about their interactions with young people?" The objective of this paper is to lay out the relevant issues and to begin the dialogue about building the capacity of employers to better support the development of our young people.

\section{Youth employment by the numbers}

In the Youth Development Study (Mortimer, 2003) conducted by Jeylan Mortimer, $82.5 \%$ of ninth graders reported ever having a steady job-steady job being defined as paid work outside the home at least weekly. Most of these youth (57\%) reported steady work at age 12 or even younger. Typical jobs at this age included mowing lawns, babysitting and shoveling snow for neighbors and friends as well as paper routes. More youth reported steady work as they became older. Only $6 \%$ of youth reported never working during the ten year study.

While employment status and hours of work per week varied throughout a young person's school years, Mortimer found the following work patterns throughout the high school years:

\begin{tabular}{|c|l|l|l|l|l|l|l|l|}
\hline & \multicolumn{2}{|c|}{ Grade 9 } & \multicolumn{2}{c|}{ Grade 10 } & \multicolumn{2}{c|}{ Grade 11 } & \multicolumn{2}{c|}{ Grade 12 } \\
\hline & Boys & Girls & Boys & Girls & Boys & Girls & Boys & Girls \\
\hline $\mathrm{N}$ & 160 & 302 & 163 & 242 & 220 & 295 & 228 & 326 \\
\hline \% employed & $40 \%$ & $63 \%$ & $42 \%$ & $52 \%$ & $53 \%$ & $63 \%$ & $58 \%$ & $70 \%$ \\
\hline $\begin{array}{c}\text { Distribution of } \\
\text { hours worked/wk }\end{array}$ & & & & & & & & \\
\hline $1-10$ & 61.9 & 61.3 & 21.5 & 32.6 & 13.2 & 20.3 & 15.4 & 12.9 \\
\hline $11-18$ & 19.4 & 19.9 & 25.8 & 34.3 & 28.2 & 29.8 & 21.1 & 31.9 \\
\hline $19-20$ & 5.6 & 8.6 & 12.9 & 12.4 & 11.8 & 14.2 & 20.2 & 18.1 \\
\hline $21-25$ & 5.6 & 5.0 & 14.1 & 7.9 & 13.6 & 18.3 & 12.7 & 19.3 \\
\hline $26-30$ & 2.5 & 3.0 & 11.0 & 9.1 & 14.5 & 12.2 & 14.0 & 10.7 \\
\hline $31-40$ & 3.8 & 1.3 & 12.9 & 2.9 & 16.4 & 3.7 & 12.7 & 5.8 \\
\hline$>40$ & 1.3 & 1.0 & 1.8 & 0.8 & 2.3 & 1.4 & 2.1 & 1.4 \\
\hline
\end{tabular}

The US Department of Labor (2000) reports that $9 \%$ of fifteen year olds were employed in an average month. By contrast, $26 \%$ of sixteen year olds and $39 \%$ of seventeen year olds were considered employed by DOL standards-worked at least one hour the previous week or who worked for a family business for no pay. This differs significantly from Mortimer's findings primarily because Mortimer asked whether the youth "ever had a steady job outside the home," while Department of Labor only counted employment status one week prior to the study week.

By any measure, however, many youth are employed and with varying results. In the best situations, young people develop meaningful skills, relationships and a better sense of themselves. In less desirable situations, part-time jobs may actually be harmful to youth.

\section{Impact of Youth Employment}

Researchers continue to debate the impact of youth employment. In When Teenagers Work, Ellen Greenberger and Laurence Steinberg (1986) note the generally negative outcomes of teenagers in the workplace. In exploring some of the stereotypical benefits of working, 
including perceived increases in a sense of responsibility, positive attitudes towards work, learning work skills, and decreases in deviant behaviors, the authors found the following:

- Responsibility: Little evidence exists that would indicate an increase in the level of personal or social responsibility.

- Learning in the workplace: Very little time is spent by teens using academic skills (reading, writing, or computation) in the typical workplace.

- Deviance: The authors note that, "it is an article of faith...that working should deter youth from crime and delinquency. And faith is usually slow to succumb to facts." According to their research, work exposure does not diminish a prior tendency toward delinquency. In fact, for middle class youth, work lead to a more significant association with the frequency of using alcohol, tobacco or other drugs. These researchers note that the more hours youth work per week, the more likely they are to use alcohol, tobacco and other drugs; to be violent or to struggle in school. Theft, materialism, cynicism and acceptance of unethical practices were also noted as potential negative outcomes of teen employment.

These researchers also make a case against work for the "opportunity costs." That is, if youth are working, they might be giving up some other developmental opportunities, which would create a developmental cost to the youth in lost opportunities. In other words, an employed youth cannot take part in as many sports, clubs, social and family activities. Those developmental opportunities, if not lost, at least suffer. Work may preclude kids from being involved as they should in school, family and community.

The Youth Development Study conducted by Mortimer shows a slightly more positive picture of youth and work. Mortimer started with 1,000 St. Paul, MN ninth graders in 1988 and followed them with interviews and surveys for 10 years until they were in their mid-twenties. Using the data, she categorized the youth into four types of workers (see Table below).

\begin{tabular}{|c|c|c|}
\hline & $\begin{array}{c}\text { Low intensity } \\
\text { ( } 20 \text { or less Hrs./Wk) }\end{array}$ & $\begin{array}{c}\text { High Intensity } \\
\text { (More than } 20 \text { Hrs. / Wk.) }\end{array}$ \\
\hline $\begin{array}{c}\text { High Duration } \\
\text { (employed most months of } \\
\text { the study period) }\end{array}$ & $\begin{array}{c}\text { Steady workers. They } \\
\text { tended to be continuously } \\
\text { employed but restricted their } \\
\text { hours. } \\
24.9 \% \text { of kids }\end{array}$ & $\begin{array}{l}\text { Most Invested workers } \\
\text { were employed most of the } \\
\text { time and worked longer hours. } \\
26 \% \text { of kids }\end{array}$ \\
\hline $\begin{array}{c}\text { Low Duration } \\
\text { (Employed less than } 1 / 2 \text { the } \\
\text { months of the study.) }\end{array}$ & $\begin{array}{l}\text { Occasional workers were } \\
\text { rarely employed and had few } \\
\text { hours when they were. } \\
23.7 \% \text { of kids }\end{array}$ & $\begin{array}{c}\text { Sporadic workers worked } \\
\text { long hours but irregularly. } \\
18.4 \% \text { of kids }\end{array}$ \\
\hline
\end{tabular}

When looking at a variety of outcomes for youth in these categories, she found that those youth that, during the study, showed signs of delinquent behavior were also found to be disengaged from school and school disengagement was found to be a predictor of hours worked. Put another way, those most engaged in work had not found ways to be meaningfully engaged in other parts of their lives and may have been using employment to have important needs met.

Mortimer's conclusions differ significantly from Steinberg's and Greenberger's in that Mortimer shows that youth find time to do what's important to them. She found that when teens worked a limited number of hours (less than 20 per week) that they still participated in extracurricular 
and community activities at the same rate as non-employed youth. However there was a decrease in the amount of time spent on household chores. There was also a pronounced decrease in television viewing and other sedentary activities. Time spent on extracurricular activities and volunteer work stayed the same. In fact, for youth in grades 11-12, workers tend to spend more time on homework than do non-workers.

Knowing that work during middle and high school often does not result in positive consequences for young people, and may even have many negative consequences, what is the solution? We know that youth work for many different reasons. Focusing on telling young people not to work is likely not a realistic strategy. But, the field can advocate for a kind of workplace that resembles a positive developmental learning opportunity for our young people. What would happen if we created a work environment, where employers act as the caring adults who are thoughtful and intentional about their interactions with young people?

\section{Workplace as a Quality Youth Development Opportunity}

In the youth development field, we understand that programs for youth have potential longterm payoffs. In Finding Out What Matters for Youth (Gambone, Klem \& Connell, 2002) the researchers documented the link between these long-term payoffs and the supports and opportunities adults had in childhood and adolescence. As youth involve themselves in quality programs, they build relationships with peers and adults, learn skills, gain knowledge and perhaps explore potential community roles. These types of positive experiences often lead to young adults who were economically self-sufficient, had stable family lives and were active in their communities.

We have assumed that youth work is done by youth workers and business people, who employ many of the same youth, are in the business of, well..., business. And the purpose of any business is to make a profit for the owners or shareholders. Businesses that fail to make a profit cease to exist. The purpose of youth serving organizations is to "help youth deal successfully with the challenges of adolescence and prepare them for the independence and responsibilities of being parents, workers, and citizens, by attempting to help youth develop competencies (National Youth Development Information website)."

However, the conclusions drawn by Gambone, Klem, and Connell are not exclusive to youth programs. The researchers state the importance of communities finding ways for youth to have key needs met. Any way that youth find to have these needs met can lead to positive longterm benefits. While there are obvious differences between youth workers and youth employers, there certainly seems to be room for crossover in terms of meeting youth needs. The purpose of this paper is to propose the possibility that important youth needs can be met in work environments as well as in youth programs and to suggest ways to improve work environments for the developmental benefits of young people.

\section{Youth Organizations Work through Employment}

The use of employment as a tool for youth work is not a new idea. For some youth serving organizations, employment is both their means and their mission. They use employment to meet the needs of young people and in doing so provide employment opportunities.

Homeboy Industries in Los Angeles, started by Father Gregory Boyle, uses employment opportunities to help young people stay out of or break out of gang life. Homeboy Bakery, Homeboy Screen Printing and Homeboy Tattoo Removal employ young people and in the process provide an economic lift to a depressed part of the city. The youth themselves, having 
turned their backs on gang life, find they can have their needs for relationships, belonging, and recognition met in other ways.

In the similarly depressed but very small town (less than 600 population) of Rothsay, MN the school owns the town's only convenience store, hardware store and lumberyard. The school uses these businesses as part of its business education program. Another group of students in an industrial arts program, using materials from the school-owned lumber yard, build a house each year that is sold to the public.

These programs and many others like them use work to bring about long-term youth outcomes. But these are first and foremost youth development programs and the people who lead them have as their primary interest the young people themselves with a secondary interest in profit. What is the role of profit oriented businesses in youth development?

\section{The Workplace as an Arena for Positive Youth Development}

After moving into a new community and inquiring about key people that impact the area's youth one business man's name, Walt Gislason, kept coming up along with the names of coaches, 4-H leaders, youth ministers and other typical youth workers. This filling station owner, Walt Gislason, was the beginning of my interest in employers and their role in youth development. Among Mr. Gislason's employees are students from alternative learning centers and community corrections, and without exception they are outstanding customer service representatives. His work is proof that paying attention to youth needs works for all youth not just the best and the brightest. Others interviewed included the manager of a department store, an electrical company trainer, a grocery store owner and a partner in a family owned meat market. These were recommended by other employers and youth workers. Comments from most of them are included in the following section as most were doing things that would be recognized as good youth development practices. It should be noted that only two of the businesses seemed at all intentional about achieving positive youth outcomes. Another business was not noted at all in the comments due to lack of evidence of any positive youth development practices.

Gisela Konopka (1973) and later, Karen Pittman (1991) identified eight critical elements essential to healthy development in young people. Employers can help young people have these needs met and at the same time build commitment of young people for the business. Walt Gislason is unfamiliar with Konopka and Pittman but he intuitively works to have these needs met in his employees. He says, "None of this is a secret but none of it happens by accident."

Following are these eight key elements (Center for 4-H Youth Development, 1996), points for employers to consider and quotes and notes from interviews with employers about their work with youth.

1. Youth feel a sense of safety and structure. Put procedures in place that keep employees safe and assure that safety procedures are covered in training.

- Consider emotional as well as physical safety. Prevent bullying, racial slurs, sexual or other forms of harassment and deal with them when they occur.

- Involve youth in determining and setting job expectations.

- Empower youth to point out safety issues. Reward them for doing so.

- Ensure that everybody is aware of emergency procedures. 
"Whenever there is an accident I wonder if I could have done more... Training for employees who work with youth is the first line of prevention."

\section{Electric Company Trainer}

2. Youth need to experience active participation, group membership and belonging. Everybody wants to belong. Building a workplace where young people feel they play a important roles will build commitment to the business.

- Be intentional about how youth will be involved in decision making. Plan for it.

- Involve youth in staff meetings. Ask for their input.

- Confront cliques and behaviors that exclude some of the group.

- Consider dress codes, uniforms, and name tags to build a team image.

"We hold contests in the store on things like signing up charge card applicants, and care plan contracts." Contributions are recognized in planned and in spontaneous ways.

Department Store Manager

One employer holds regular employee meetings where the importance of customer service is impressed on employees. "I ask how they individually impressed a customer. When one starts, others always join in." It seems to me this might be similar to what happens in opening ceremonies of various organizations that serve to bind a group and signal belonging.

3. Develop self-worth through meaningful contributions. Young people will feel free to contribute if they feel their contributions are accepted, acknowledged and appreciated.

- Ask for input from youth in solving problems.

- Reward creativity, innovation and initiative.

- Train employees to conduct employee meetings.

"Break rooms are arranged to be comfortable and welcoming. Experienced associates are encouraged to sit and visit with new staff. During daily meetings, we do a person by person check-in to get input and deal with problems before the store opens."

Department Store Manager

4. Experiment to discover self, gain independence and control over one's life. Youth are encouraged to try new things and learn about themselves. As a result they discover and practice their interest and skills, test their independence and take control of their lives.

- Help youth find what they are good at in your business.

- Rotate them among different jobs to help them find their niche.

- Give youth increasing amounts of responsibility and independence as they prove themselves.

"If the employee agrees that his behavior is problematic, then I put it back on him for suggestions. ('If you were me and I was you what would you have me do?') We agree on some solutions and on a time to visit again."

Filling Station Owner 
5. Develop significant positive relationships with peers and at least one adult. Youth with positive relationships tend to do better in all areas of their lives.

- Youth should not work alone for long periods of time.

- Make sure they have opportunities on every shift to interact with other youth and with adults.

- Mentor them and encourage other adult employees to act as mentors. Take opportunities to work one-on-one with each teen employee.

"Nobody works alone!"

$$
\text { Meat Shop Owner }
$$

"Occasionally we come across a journeyman who is a good electrician but a poor teacher or a poor role-model. In such cases we limit the amount of time any one apprentice spends with that individual."

\section{Electric Company Trainer}

6. Discuss conflicting values and form their own. Work can be a place to experience and talk about values and topics that are important to them.

- Demonstrate a high value on promoting acceptance for all. Know that employees come from different backgrounds and come to work with different values and beliefs.

- Make opportunities to build positive values in the workplace.

- Be aware of your own values and beliefs.

"Several years ago the store received a shipment of t-shirts with vulgar sayings. As a group, sales associates decided they did not want them in the store and I had them returned."

Department Store Manager

"When I noticed one of my kids smoking off the job I called the boy's mother to tell her about what a valued employee her son was. I also mentioned that I had noticed him smoking one day and that this bothered me. I also took the boy aside and told him what I had seen and that 'this kind of behavior is below your standard. "'

Filling Station Owner

One employer was unsure what I meant by "values" and had difficulty thinking of anything he did in his business that would help youth in this area. However, before I left the store he led me to a display case with pictures of troops in Afghanistan to whom the business had sent product. Letters from the troops were also displayed. He hadn't given a thought to how this simple activity might build values.

7. Feel pride of competence and mastery. Young people want to know that they are doing good work and appreciate increasing levels of trust.

- Institute a step program for employees that allows for increasing levels of responsibility.

- Call employees by name. 
- Let parents know their son or daughter is a valued part of your business.

"Contributions are recognized in planned and in spontaneous ways. When I get a call from a customer about great service I just walk onto the floor and make an announcement."

Department Store Manager

There are binders full of compliments from customers. "When a card is received noting good service, the employees involved are recognized. In training, employees are told it is their job to get into the book."

Filling Station Owner

\begin{abstract}
8. Expand their capacity to enjoy life and know that success is possible. Make work an opportunity for young employees to enjoy life. Help them grow from successes and failures.

- Help employees see how their contributions have made a difference to the business.

- Celebrate both successes and failures.

- Help employees see when it is time to move on and help them do so. Make yourself available to write reference letters.

"I had an employee who took a job... (in a community 15 miles away). He came back to work days before starting the new job because he didn't have any way to get there. I took him to a car dealership and to the bank to help him deal on a car and get a loan."
\end{abstract}

Filling Station Owner

\title{
Conclusion
}

Youth may take a job for money but they are more likely to keep the job if it helps them fulfill other needs. Youth development is not the primary concern of employers, especially business people who have to make a profit. But paying attention to youth needs seems to be something employers can do to keep their employees interested and that positively affects the bottom line.

In the employer-employee relationship almost exclusive emphasis has been placed on preparing youth employees for work. In doing so an assumption is made that it is youth who are lacking the skills necessary to make the relationship work and to some extent this is the case. Young people new to the workplace may need assistance. If they are in doubt of the importance of showing up on time and working the entire shift then they need to learn how important this is to employers. Some young people have learned to take a nonchalant attitude toward their school work doing no more than is required to get by-and they get by. At some point they need to understand that doing just enough to get by will not serve them well in the workplace. Due to their lack of experience they may not be aware how important these things are to supervisors, managers and business owners. A Chamber of Commerce director noted many frustrations his members have with youth even from the time applicants try to fill out a basic application.

Sometimes young workers do all that is asked of them and they still have a poor employment experience. One young person was told by her coworkers in a fast food restaurant that "you'll 
learn to hate it here but we all get used to it." When another youth was asked why she did not apply at a nearby, upscale supper club she remarked, "No way! They treat kids like shit at that place!" (There was clearly some talk among friends at school and the word was out about that place of business.) One young person talked about driving to work through a blizzard only to find the business closed. There was a definite safety issue as the restaurant made no attempt to contact its employees about the weather related closing.

Problems with bringing youth into the workforce with positive results clearly do not rest only on the youth themselves. A piece that is often lacking is preparation of the employers and other workplace adults who have contact with our youth. Youth workers, adults who have devoted their lives to working with youth in programs, understand the importance of professional development. They may belong to professional associations, attend conferences, read or simply talk among themselves to stay current in the field. Interviews with employers indicate they have no way of staying current in their work with youth. In fact, none had given a thought to this as being important-and with predictable results. Even so, some employers do quality youth development in the context of doing business. However, it is too often a fortuitous combination of personality and luck that allows business people to connect with their youth employees in meaningful ways.

\section{Questions and challenges for the future of youth development and employment:}

- Youth development training for employers has been lightly attended. How do we create interest among employers to do youth development as part of their business? What encouragement can be given to seek training in this area?

- Not all employers are created equal and some employment situations are most certainly harmful to the development of young people. How do we measure quality in employment? How and at what point does the scale tip from positive to negative? How do we help youth and their parents distinguish between positive and negative employment experiences?

- In "Learning Well at Work" (Hamilton \& Hamilton, 1997) the researchers discuss the many benefits of a close link between school and part-time work. However, past efforts to formalize those links have not been well received. How do we create intentional learning opportunities in communities including opportunities linked to schools?

According to Stephen Hamilton (1990), the student graduating from high school with a 4-point GPA and the one graduating with a 2-point GPA have basically the same shot at successful and well paying careers. The kind of performance learned in school is different from the performance required in the workplace so any graduate able to learn what the workplace requires can achieve. Therefore, those businesses and youth development organizations that help young people learn to navigate the adult world of work are extremely important. And that brings us back to the importance of employers filling important roles for young people in communities. Given today's economic reality, more youth development programs are falling by the wayside. Where programs have been lost employers may play an even more important role in the development of our youth especially for youth who have not found other meaningful ways to link with the community. 


\section{References}

Center for 4-H Youth Development. (1996). Keys to Quality Youth Development. Educational Development Systems, University of Minnesota Extension Service.

Gambone, M.A., Klem, A.M., \& Connell, J.P. (2002). Finding Out What Matters for Youth: Testing Key Links in a Community Action Framework for Youth Development. Philadelphia: Youth Development Strategies, Inc., and Institute for Research and Reform in Education.

Greenberger, E., \& Steinberg, L. (1986). When Teenagers Work: The Psychological and Social Costs of Adolescent Employment/ Ellen Greenberger, Laurence Steinberg. New York: Basic Books.

Hamilton, M.A., \& Hamilton, S.F. (1997). Learning Well at Work: Choices for Quality. School to Work Opportunities, Cornell Youth and Work Program, Cornell University.

Hamilton, S.F. (1990). Apprenticeship for Adulthood: Preparing Youth for the Future. New York: Free Press; London: Collier Macmillan.

Konopka, G. (Fall, 1973). "Requirements for the Healthy Development of Adolescent Youth, " Adolescence, VIII, 31.

Mortimer, J.T. (2003). Working and Growing up in America. Cambridge: Harvard University Press.

National Youth Development Information. "What is Youth Development?" www.nydic.org/nydic

Pittman, K. (June, 1991). Promoting Youth Development: Strengthening the Role of Youth Serving and Community Organizations. Washington, DC: Academy for Educational Development.

U.S. Department of Labor, Bureau of Labor Statistics. (2000). "Report on Youth Labor." (p. 30). www.bls.gov/opub/rylf/pdf/chapter4.pdf

(C) Copyright of Journal of Youth Development Bridging Research and Practice. Content may not be copied or emailed to multiple sites or posted to a listserv without copyright holder's express written permission. Contact Editor at: patricia.dawson@oregonstate.edu for details. However, users may print, download or email articles for individual use.

ISSN 2325-4009 (Print); ISSN 2325-4017 (Online) 